\title{
Integration of Asynchronous and Synchronous Gameplay to Improve Pupils' Vocabulary
}

\author{
Hanani Shamsudin 1,2, Harwati Hashim ${ }^{2 *}$, Melor Md. Yunus ${ }^{2}$ \\ ${ }^{1}$ SK Putrajaya Presint 11(2), Putrajaya, Malaysia \\ ${ }^{2}$ Faculty of Education, Universiti Kebangsaan Malaysia, Bangi, Malaysia \\ Email: *harwati@ukm.edu.my
}

How to cite this paper: Shamsudin, H., Hashim, H., \& Yunus, M. Md. (2019). Integration of Asynchronous and Synchronous Gameplay to Improve Pupils' Vocabulary. Creative Education, 10, 3101-3106. https://doi.org/10.4236/ce.2019.1012234

Received: October 16, 2019

Accepted: November 26, 2019

Published: November 29, 2019

Copyright $\odot 2019$ by author(s) and Scientific Research Publishing Inc. This work is licensed under the Creative Commons Attribution International License (CC BY 4.0).

http://creativecommons.org/licenses/by/4.0/ (c) (i) Open Access

\begin{abstract}
It has been many years since the influence of British colonial in Malaysia that English becomes a compulsory subject to be taught in the classroom. It's a phenomenon nowadays to teach English to young learners. However, it is found that using conventional methods in the classroom is not suitable for Alpha generation as they tend to feel bored easily. To equip the Alpha generation with fun learning, 21st-century learning or PAK21 approach is implemented in the school so that it can produce pupils with higher creative thinking and pupils with better human values. It is also formulated in the second wave of Malaysia Education Blueprint 2013-2025. Teaching a primary school pupil at an urban school is tough as pupils in the urban school are moving forward in a blink of eyes and they are more exposed to the latest digital trending compared to a rural school. However, despite the exposure, pupils still face several problems while learning English language. Hence, this paper reviews asynchronous and synchronous gameplay as the practical tools for teaching vocabularies to pupils. This paper deals with a literature review of teaching English vocabulary to young learners using integrated asynchronous and synchronous gameplays. This paper will also discuss the importance of using gameplay in teaching vocabulary, why is it important to blend both gameplays and how the approaches help in teaching and learning vocabulary. Lastly, this paper discusses the challenges face by teachers when implementing integration of asynchronous and synchronous gameplay to teach vocabulary to young learners.
\end{abstract}

\section{Keywords}

Asynchronous and Synchronous Gameplay, 21st Century Learning, Learning Vocabulary, Fun Learning, Blended Gameplay 


\section{Introduction}

Teaching vocabulary towards level 1 primary school pupils (Year 1 - Year 3) had been a major challenge for most Malaysian teachers. Many researches had been conducted on how to overcome problems arose when learning English language toward pupils in these age range. Problems come from many aspects such as environment, culture, facility, pupils' problem, teacher's problem and many more. This paper, on the other hand, focuses more on how the integration of asynchronous (traditional) and synchronous (digital platform) could help in advancing pupils' vocabulary. Choosing games as a tool for teaching could be a suitable approach for the pupils as they can learn and play at the same time. It is children nature to play and this proposed method can help pupils to learn vocabulary without getting bored. This fun learning also provides many benefits that will be discussed in this paper. According to Harmer (1991), vocabulary is important to be mastered as it is "the vital organs and flesh". Hence, this paper will be divided into five parts. The first part is literature review with thematic themes and second part will be the implications when implementing suggested activity in the classroom.

\section{Using Blended Gameplay in Learning Vocabulary}

\subsection{Young Learners}

There are many definitions related to who is young learners. According to Bakhsh (2016), young learners are defined as children who are in the first year of elementary schooling to twelve years old of age. But, Philips (1993), disagree and stated that children's age is not the only aspect of how mature they are, gender, culture, parents and environment (city or rural) were also the aspects of it. Learners need to be curious, imaginative and playful (Slattery \& Willis, 2001). Thus, teachers need to provide variety of activities to provide them with such criterion. Philips (1993) also stressed the importance of simplifying activities, provide task that is motivating for young learners to be more comfortable in learning.

\subsection{Vocabulary}

According to Ghanbaran \& Ketabi (2014), they stated that one crucial challenge for language learners is teaching vocabulary. This is supported by Linse (2005) in which she said that to master English skills, such as pronunciation and structure, one need to master vocabulary as learning the words and understand the meaning behind the words help one to master their English skills. A young learner needs to learn at least one to two thousand words for them to be master in speaking and writing English (Cameron, 2001). Hence, teacher plays an important role to make sure young learners able to grasp vocabulary at their hand.

\subsection{How Is Vocabulary Learned?}

Vocabulary can be learnt in many approaches. Mostly in repetitive way, in which children keep on repeat the words learnt by pronouncing it several times. It can 
also be aided with visual aids such as picture. There is also another approach in which the method needs total body movement by the children. As children are keen to be active, this Total Physical Response (TPR) should be used by the teacher to attract children to be more focus in a fun way. Nevertheless, children should know the existing of synonym and antonym words. As Thornbury (2002) said, children should be able to categorize the moment they speak, and they should be able to know how to construct complex ideas mainly by building a network in their mind between the labelling words they learnt.

\subsection{Teaching Vocabulary Using Games}

As TPR is mention before, it is known that using games can help pupils to move their body in the classroom. Pupils can gain both of the benefits in which learning and playing are meaningful. The element in PAK 21 rush teachers to understand that learning should not be conventional as many fun teachings could also help pupils to learn. By implementing games suggested by PAK21 such as gallery walk, quiz and many more, teachers can expand pupil's creative language skill, and this been agreed by Halliwell (1992) in which he stated that teachers should provide a communicative atmosphere for pupils to express themselves. What is a game? Richard \& Rodgers (2001) along with Rixon (1981) stated that game needs to be one or more player to play in a goal-oriented, rule-governed in which the game is engaging, and body movement is guaranteed to produce fun while playing. Bakhsh (2016) stated that to be able to master the linguistic part of a language, a well-trained teacher is needed. Hence, teachers should first understand what a game is and how a game could help pupils in learning. Realizing this, asynchronous, synchronous gameplay as well as blended learning and how does it help in learning will discuss further in the next paragraph.

\subsection{Asynchronous, Synchronous and Blended Learning}

Nowadays, young learners are more skilled in term of digital platform compare to young learners 15 years ago in which not many young learners own their mobile phone in Malaysia. Nevertheless, owning a mobile phone, tab or an I-pad doesn't make one a master of ICT. Hence, educators especially teachers in the school should provide learners in the school with such skill so that pupils will be able to learn and mastering the language skills they had problems with.

Hence, providing an interactive virtual learning platform and cooperate it with pupils in a classroom then playing a game in the classroom online or offline can be a great help for pupils in which pupils will be able to be more familiar with the learning. This platform could also help pupils to gain help from others outside from school by going through the searching database on the internet such as YouTube, Google and then aided with games in the classroom. For example, the topic is about sea creature. A teacher could play a video song contains many sea creatures in which pupils can singing and dancing the song when hearing it aided with learning in the classroom where vocabulary is been re- 
peated many times and lastly quiz can be given online or offline by a teacher to look on pupils understanding.

According to Singh (2003), he stated that learning should be a process, and this is related to the concept of blended learning. Malaysia with our latest technologies in which web-based learning is no longer something rare to see in the classroom (Halim \& Hashim, 2019; Yunus \& Suliman, 2014), teachers become more and more anxious and excited to implement it in the classroom as to together follow with the government policy that wants teachers to include technology in the classroom (Rafiq \& Hashim, 2018). There is also methodology in which e-learning is combined with conventional method in the classroom and this hybrid teaching methodology is being called as blended learning. Teachers can use it by asynchronous and synchronous.

Many definitions can be found on asynchronous. Some researchers said that asynchronous is offline platform such as forums, email and web. Some researchers said that asynchronous games mean gameplay in the classroom such as miming, role play, Simon's say, gallery walk and many more. As for this paper, the definition of asynchronous gameplay is more on the games in the classroom in which miming is implemented. Synchronous in the other hand is the online platform where teacher uses Web, Google, YouTube to aid the learning and also using games online such as Collocations, Kahoot, Wattpad and many more as a platform to learn vocabulary online. It is a full utilization of integrating application of ICT in the learning.). It is also found that majority of learners had high positive attitude when use ICT in learning English (Hashim, Yunus, \& Embi, 2016; Hashim, Yunus, \& Embi, 2018; Yunus, Lubis, \& Chua, 2009). Both asynchronous and synchronous were chosen as both gameplays is seen to complete each other in classroom learning. Using both gameplays can be more meaningful towards pupils that learning.

\section{Implications and Conclusion}

Researches had found that by implementing games in the classroom, children learn better (Prensky, 2003; Leemkuil, 2006; Gee, 2012; Tüzün et al. 2009; Van Eck, 2006). Lewis (1991) also claims that this happens because children's nature is to play. Hence, this is why games are so popular among games inside the classroom, outside the classroom no matter in what platform there are in, virtual or reality. Research on students' perception on vocabulary learning through synchronous and asynchronous games conducted by Karaaslan, Kilic, Yalcin, \& Gullu (2018) found a loophole in which some students rather choose to learn vocabulary through synchronous where they enjoy digital platform and some like it better by asynchronous where they find games are better played in the classroom through conventional style. Teaching young learners' vocabulary could be exhausted for a teacher as pupils tend to forget what had been learned when moving forward to other topics. However, by implementing a suitable synchronous blended with asynchronous gameplay in the classroom during 
learning could be fun and engaging. It could also be meaningful for pupils because they learn it in both ways. Asynchronous focus on their body movement where they can remember what they do when learning and Synchronous provide pupils with moving visual and fun online activity. In conclusion, this paper could be an aid for pupils who trying to find a solution to help their pupils in learning vocabulary. However, research should be done to look at the success of the methods suggested and the development of vocabulary among pupils.

\section{Funding}

This research was supported by the grant from Universiti Kebangsaan Malaysia KRA-2018-044, GG-2019-017 and PP-FPEND-2019.

\section{Conflicts of Interest}

The authors declare no conflicts of interest regarding the publication of this paper.

\section{References}

Bakhsh, S. (2016). Using Games as a Tool in Teaching Vocabulary to Young Learners. English Language Teaching, 9, 120. https://doi.org/10.5539/elt.v9n7p120

Cameron, L. (2001). Teaching Language to Young Learners. Cambridge: Cambridge University Press. https://doi.org/10.1017/CBO9780511733109

Gee, J. P. (2012). The Old and the New in the New Digital Literacies. The Educational Forum, 76, 418-420. https://doi.org/10.1080/00131725.2012.708622

Ghanbaran, S., \& Ketabi, S. (2014). Multimedia Games and Vocabulary Learning. Theory and Practice in Language Studies, 4, 489-496. https://doi.org/10.4304/tpls.4.3.489-496

Halim, M. S. A. A., \& Hashim, H. (2019). Integrating Web 2.0 Technology in ESL Classroom: A Review on the Benefits and Barriers. Journal of Counseling and Educational Technology, 2, 1-8. https://doi.org/10.32698/0421

Halliwell, S. (1992). Teaching English in the Primary Classroom. New York: Longman.

Harmer, J. (1991). The Practice of English Language Teaching: New Edition. New York: Longman.

Hashim, H. M. M., Yunus, M. M., \& Embi, M. A. (2016). Pre-University English as Second Language (ESL) Learners' Attitude towards Mobile Learning. Creative Education, 7, 1147. https://doi.org/10.4236/ce.2016.78119

Hashim, H. M. M., Yunus, M. M., \& Embi, M. A. (2018). Factors Influencing Polytechnic English as Second Language (ESL) Learners' Attitude and Intention for Using Mobile Learning. Asian ESP Journal, 14, 195-208.

Karaaslan, H., Kılıç, N., Guven Yalcin, G., \& Gullu, A. (2018). Students' Reflections on Vocabulary Learning through Synchronous and Asynchronous Games and Activities. Turkish Online Journal of Distance Education, 19, 53-70. https://doi.org/10.17718/tojde.444640

Leemkuil, H. (2006). Is It All in the Game? Learner Support in an Educational Knowledge Management Simulation Game. Unpublished Doctoral Dissertation, Enschede: University of Twente.

Linse, C. (2005). Practical English Language Teaching: Young Learners. New York: McGraw- 
Hill.

Philips, S. (1993). Young Learners. Oxford: Oxford University Press.

Prensky, M. (2003). Digital Game-Based Learning. Computers in Entertainment (CIE), 1, 21. https://doi.org/10.1145/950566.950596

Rafiq, K. R. M., \& Hashim, H. (2018). Augmented Reality Game (ARG), 21st Century Skills and ESL Classroom. Journal of Educational and Learning Studies, 1, 29-34. https://doi.org/10.32698/0232

Richard, J. C., \& Rodgers, T. (2001). Approaches and Methods in Language Teaching. Cambridge: Cambridge University Press. https://doi.org/10.1017/CBO9780511667305

Rixon, S. (1981). How to Use Games in Language Teaching. London: Macmillan.

Singh, H. (2003). Building Effective Blended Learning Programs. Educational Technology, 43, 51-54.

Slattery, M., \& Willis, J. (2001). English for Primary Teachers. Oxford: Oxford University Press.

Thornbury, S. (2002). How to Teach Vocabulary. Harlow: Longman.

Tüzün, H., Yılmaz-Soylu, M., Karakus, T., Inal, Y., \& Kızlkaya, G. (2009). The Effects of Computer Games on Primary School Students' Achievement and Motivation in Geography Learning. Computers \& Education, 52, 68-77. https://doi.org/10.1016/j.compedu.2008.06.008

Van Eck, R. (2006). Digital Game-Based Learning: It's Not Just the Digital Natives Who Are Restless. EDUCAUSE Review, 41, 1-16.

Yunus, M. M., \& Suliman, A. (2014). Information \& Communication Technology (ICT) Tools in Teaching and Learning Literature Component in Malaysian Secondary Schools. Asian Social Science, 10, 136. https://doi.org/10.5539/ass.v10n7p136

Yunus, M. M., Lubis, M. A., \& Lin, C. P. (2009). Language Learning via ICT: Uses, Challenges and Issues. Wseas Transactions on Information Science and Applications, 6, 1453-1467. 